\title{
Recorregut de recerca geològica i minera per les comarques del Bages i del Solsonès: des de Callús i Sant Mateu de Bages cap a Castelltallat, Prades de la Molsosa, Pinós y Matamargó
}

Josep Maria Mata-Perelló

Joaquim Sanz Balagué

\section{XARAGALL \\ REVISTA DE CIÈNCIES DE LA CATALUNYA CENTRAL}

\section{n. 3}

MARÇ 2014 


\title{
RECORREGUT DE RECERCA GEOLÒGICA I MINERA PER LES COMARQUES DEL BAGES I DEL SOLSONĖS: DES DE CALLÚS I SANT MATEU DE BAGES CAP A CASTELLTALLAT, PRADES DE LA MOLSOSA, PINÓS Y MATAMARGÓ
}

\author{
Josep Maria Mata-Perelló \\ Museu de geologia Valentí Masachs, Escola Politècnica Superior d'Enginyeria de Manresa \\ (EPSEM), Universitat Politècnica de Catalunya · BarcelonaTech (UPC), 08272 Manresa, Spain
}

Joaquim Sanz Balagué

Departament d'Enginyeria Minera i Recursos Naturals (EMRN), Escola Politècnica Superior d'Enginyeria de Manresa (EPSEM), Universitat Politècnica de Catalunya - BarcelonaTech (UPC), 08272 Manresa, Spain

Paraules clau: Depressió geològica de l'Ebre; Eocè; Oligocè; Bages; Solsonès; mineralogia

\begin{abstract}
Resum
Itinerari realitzat el dia 16 de gener del 2013. En aquesta ocasió, la totalitat del recorregut de I'itinerari discorrerà per la Depressió Geològica de l'Ebre (i més concretament, ho farà de forma totalment exclusiva per la denominada Depressió Central).

Així, al llarg de tot el recorregut de l'itinerari s'aniran trobant afloraments dels materials cenozoics que reblen l'esmentada depressió. Molt sovint, aquests materials els veurem recoberts per terrenys quaternaris de caràcter eminentment detrític, formats majoritàriament $a$ partir de l'erosió dels anteriors. Els materials que anirem trobant, es reparteixen entre la Formació Artés, la Formació Súria, la Formació Cardona i la Formació Solsona, fonamentalment. Totes elles pertanyen a I'Eocè; tot i que la primera es troba al trànsit entre aquest període i l'Oligocè.

Per d'altra banda, la totalitat del recorregut discorrerà per les comarques del Bages i del Solsonès, integrades dintre de la Catalunya Central. Així, els primers trams del recorregut, entre Callús i les immediacions de Prades de la Molsosa, es realitzaran per la comarca del Bages. La resta del recorregut ja es farà per la comarca del Solsonès.
\end{abstract}




\section{Objectius fonamentals d'aquest itinerari}

Els objectius fonamentals d'aquest recorregut de caràcter geològic i miner, poden concretar-se en els següents aspectes.

1. Reconeixement de les característiques fonamentals de la Depressió Geològica de l'Ebre (per la qual transitarà la totalitat del recorregut). Al mateix temps, i si s'escau, s'efectuarà una visió a distancia de les altres dues unitats que constitueixen el territori català, concretament del Sistema Pirinenc (situat al Nord del recorregut) i del Sistema Mediterrani (situat al Sud).

2. Observació dels materials que reblen la depressió anterior. Aquests materials pertanyen a les següents formacions: Formació Artés, Formació Súria, Formació Cardona i Formació Solsona. Les dues primeres i la darrera les trobarem a la superfície; mentre que la tercera es troba al subsòl de la comarca. Totes tres unitats formen part dels materials cenozoics que reblen la depressió i pertanyen a l'Eocè-Oligocè.

3. Observació dels diferents accidents tectònics que es troben al llarg del recorregut, en especial de I'Anticlinal de la Falla del Mig Món (Súria) y de l'Anticlinal de la Muntanya de Sal (Cardona).

4. Observació dels diferents LIG (Llocs d'interès Geològic) relacionats amb els anteriors accidents.

5. Observació de les diferents explotacions mineres que anirem trobant al llarg del recorregut d'aquest itinerari. En concret, i a distancia, veurem les actuals explotacions de la Mina de Súria i també la Mina de Cardona. Aquests elements son uns LIPM (Llocs d'interès del Patrimoni Miner) de la comarca del Bages. També, si s'escau, s'observaran les antigues explotacions de les calcolutites rogenques de la Formació Artés, que trobarem entre Callús i Sant Mateu de Bages.

6. Observació si s'escau, de les relacions entre les explotacions anteriors i el Medi Natural de la comarca del Bages.

\section{Antecedents bibliogràfics}

Pel que fa al recorregut del present itinerari, cal dir que no coneixem l'existència de cap altre recorregut similar, per aquests indrets. En aquest cas aquest itinerari constitueix una primícia. Existeixen diversos antecedents parcials y generals nostres de tipus bibliogràfic.

Pel que fa a la descripció de les mineralitzacions situades a les comarques per les quals discorre l'itinerari, farem esment d'uns altres treballs nostres; concretament de Mata-Perelló (1991 i 1994).

I, finalment, pel que fa a l'estructura geològica de la zona per la qual discorre l'itinerari, farem esment dels treballs de: Guimerà et altri (1982) i de Riba et altri (1976). Tots dos fan referència a la geologia dels Països Catalans. També farem esment dels treballs d l'IGME, relatius al indrets per on transita I itinerari. Això és IGME (1975 i 1982). Igualment, farem esment d dos treballs generals: Mata - Perelló (1984) i RIBA (1967).

Tots aquests treballs, figuren esmentats per ordre alfabètic a l'apartat dedicat a la bibliografia esmentada. 


\section{Descripció de l’itinerari}

Aquest recorregut transitarà solament per la Catalunya Central, i en concret per les comarques del Bages i del Solsonès. Per d'altra banda, sempre dintre de la Depressió Geològica de I'Ebre. Així, el recorregut de l'itinerari s'iniciarà a les immediacions de la població de Callús, dintre de la comarca del Bages, per on s' efectuarà la primera aturada. Tot seguit es dirigirà cap a Sant Mateu de Bages. En aquest tram s'efectuaran dues noves aturades. Després, des de la població anterior, el recorregut es dirigirà cap a Castelltallat i cap a Prades de la Molsosa. En aquest recorregut s'efectuaran dues noves aturades, entrant desprès a la comarca del Solsonès.

Desprès el recorregut es dirigirà cap a la Molsosa i cap a Quadrells. A partir d`aquí s'iniciarà una fillola per tal d'anar cap a les immediacions de Sant Pesselaç (Sant Pere dels Arcs), per fer una nova aturada, entrant momentàniament a la comarca d'Anoia, també de la Catalunya Central. Posteriorment, des de les immediacions de Quadrells, el recorregut es dirigirà cap al poble de Pinós i cap el Santuari de Pinós, realitzant-se dues noves aturades. Tot seguit, el recorregut anirà cap a Su, anat després cap a Cardona, fins trobar el trencall de Matamargó, per on es farà una nova aturada, després d'haver entrat lleugerament a la comarca del Bages. Finalment, des de Matamargó, el recorregut es dirigirà cap a la carretera de Salo a Vallmanya, finalitzant el recorregut prop del primer poble, quasi a tocar de nou, de la comarca del Bages.

\section{Advertiment previ}

Com en altres recorreguts de recerca geològica i mineralògica ..., en aquest si es disposa del temps suficient, poden efectuar-se passant per totes les parades i filloles. En cas contrari, recomanem prescindir de les anomenades parades - condicionals.

També cal fer esment, de que alguns trams del recorregut es faran per camins en mal estat de conservació, per la qual cosa serà millor fer-los a peu. Tot i així, en aquest recorregut no trobarem gaires recorreguts per camins en mal estat de conservació.

En qualsevol cas, i com és natural, cal tenir sempre una cura molt especial de respecte a la natura, al llarg de tot el recorregut de l'itinerari.

\section{Descripció de l'itinerari}

Com de costum, estructurarem el recorregut de l'itinerari en una sèrie de PARADES, que tot seguit anirem veient. En cadascuna d'aquestes aturades farem un breu comentari (geològic o mineralògic, segons s'escaigui).

Per d'altra banda, en cada cas indicarem, entre parèntesi, el full topogràfic on es troba I'aturada. Per fer-ho, utilitzarem els fulls editats per I'Instituto Geográfico y Catastral de España, publicats a l'escala de 1:50.000. En aquest cas, els fulls seran els següents: $\mathbf{3 3 0}$ (o full de Cardona), 362 (o de Calaf) y $\mathbf{3 6 3}$ (coneguda com a full de Manresa). Així doncs, la relació de les aturades que composen el recorregut d'aquest itinerari, és la següent: 


\subsection{Parada 1 - condicional. carretera C - 55, variant de Callùs. accés al cementiri. (terme municipal de Callús, comarca del Bages). (Full 363)}

El recorregut de l'itinerari, caldrà començar-lo en aquest indret situat prop del poble de Callús, concretament a la variant de la carretera $C-55$, just prop de l'indret on hi ha l'accés al Cementiri Municipal de Callús.

Aquest indret es troba al bell mig de la Depressió Geològica de '`Ebre, entre afloraments de les calcolutites i dels gresos rogencs de la Formació Artés. Precisament, en aquest indret apareixen aquests materials a la vora de la carretera. Aquí, aquests materials cenozoics pertanyen a l'Eocè.

Per d'altra banda, en aquest lloc es pot veure una discordança angular entre els materials cenozoics acabats d’esmentar i uns nivells detrítics quaternaris, del Pleistocè, els quals formen part de la terrassa baixa del riu Cardener. (fotografia 1 ).

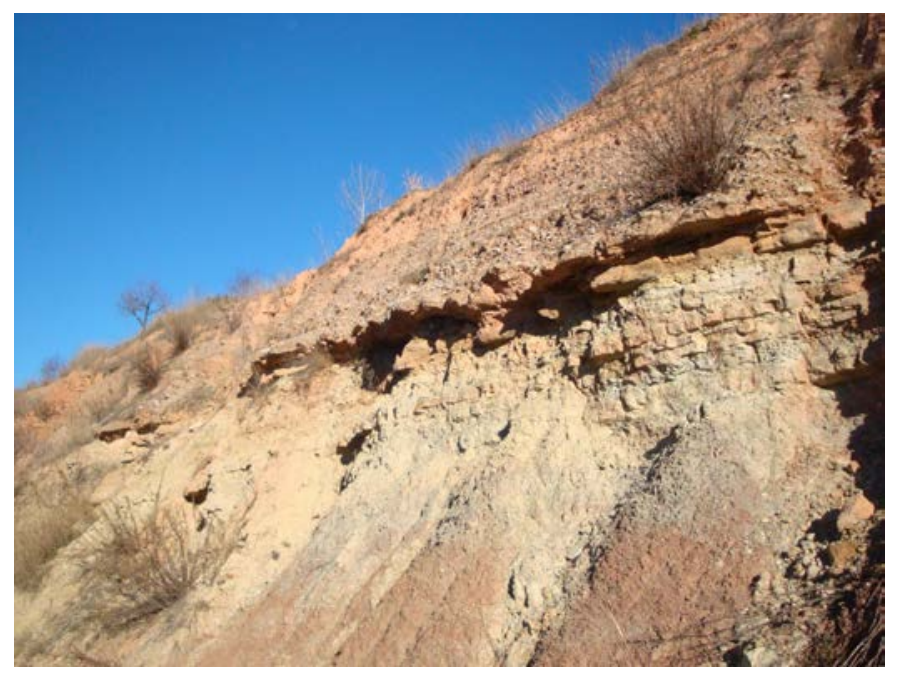

Fotografia 1. Discordança angular entre els materials de la Formació Artés (aquí de l'Eocè) i la Terrassa Baixa del Cardener (del Pleistocè), a Callús

\subsection{Parada 2. Explotacions de calcolutites de Callùs i de Sant Mateu de Bages. carretera BV - 3003, immediacions del Km 3, (terme municipal de Callús, comarca del Bages). (Full 362).}

Desprès de realitzar \aturada anterior, cal anar cap el poble de Callús, entrant per \antiga carretera C 1410 - z. Després, dintre del poble, cal agafar la carretera local BV - 3003, la qual condueix cap a Sant Mateu de Bages. Després de creuar el riu Cardener, ens caldrà començar a pujar cap al poble acabat d`esmentar. A uns $3{ }^{`} 5 \mathrm{Km}$ de la parada anterior n'efectuarem una altra. 
En aquest recorregut, haurem trobat afloraments dels materials rogencs esmentats a l'aturada anterior. Es tracta dels nivells de gresos i calcolutites rogenques de la Formació Artés. Aquests són els materials que es troben a l'indret de la present aturada. Cal dir que aquí predominen les calcolutites, sovint molt argiloses. ( fotografia 2).

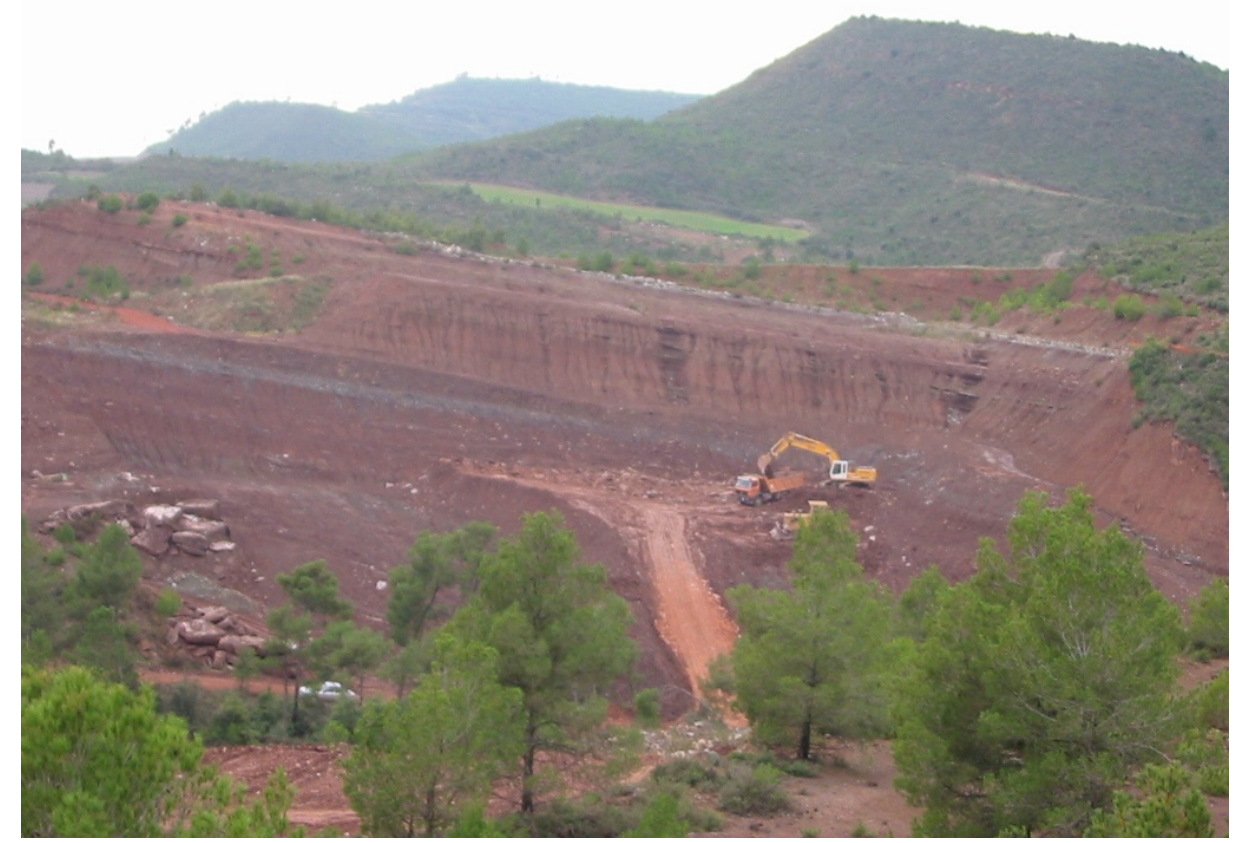

Fotografia 2. Una de les antigues explotacions de les calcolutites rogenques de la Formació Artés

En aquest indret hi ha hagut una sèrie d'explotacions de les calcolutites argiloses, per tal d`esser emprades per a la fabricació de rajoles. Tot i així, a \actualitat es troben aturades totes les explotacions i també la fàbrica. Per d’altra banda, cal dir que darrerament hi ha l'intent de situar un abocador de deixalles on hi havia les explotacions. recorregut de l'itinerari, caldrà començar-lo en aquest indret, situat prop del poble de Callús, concretament a la variant de la carretera $\mathrm{C}-55$, just prop de l'indret on hi ha l'accés al Cementiri Municipal de Callús.

\subsection{Parada 3. trencall de Sant Mateu de Bages, carretera BV - 3003, (terme municipal de Sant Mateu de Bages, comarca del Bages). (Full 362).}

Desprès de realitzar l'aturada anterior, cal acabar d'arribar al poble de Sant Mateu de Bages. En arribar-hi, quasi al trencall que es dirigeix cap el poble, farem una nova aturada, a uns $3 \mathrm{Km}$ de l’anterior.

En aquest recorregut, hem continuat trobant els materials esmentats a les aturades anteriors. Així, haurem vist afloraments dels gresos i calcolutites rogenques de la Formació Artés. Aquest són també els materials que apareixen a l'indret de l'aturada. Tot i que ara predominen els gresos. Tanmateix hi ha diversos paleocanals. 
Des d'aquest indret, mirant cap a l'Est, cap a Súria es poden veure les escombreres de les explotacions de potassa; és a dir: els depòsits de sal comuna, la qual constitueix la ganga de les explotacions de silvinita. Tanmateix es poden veure les instal-lacions d'IBERPOTASH. ( fotografia 3).

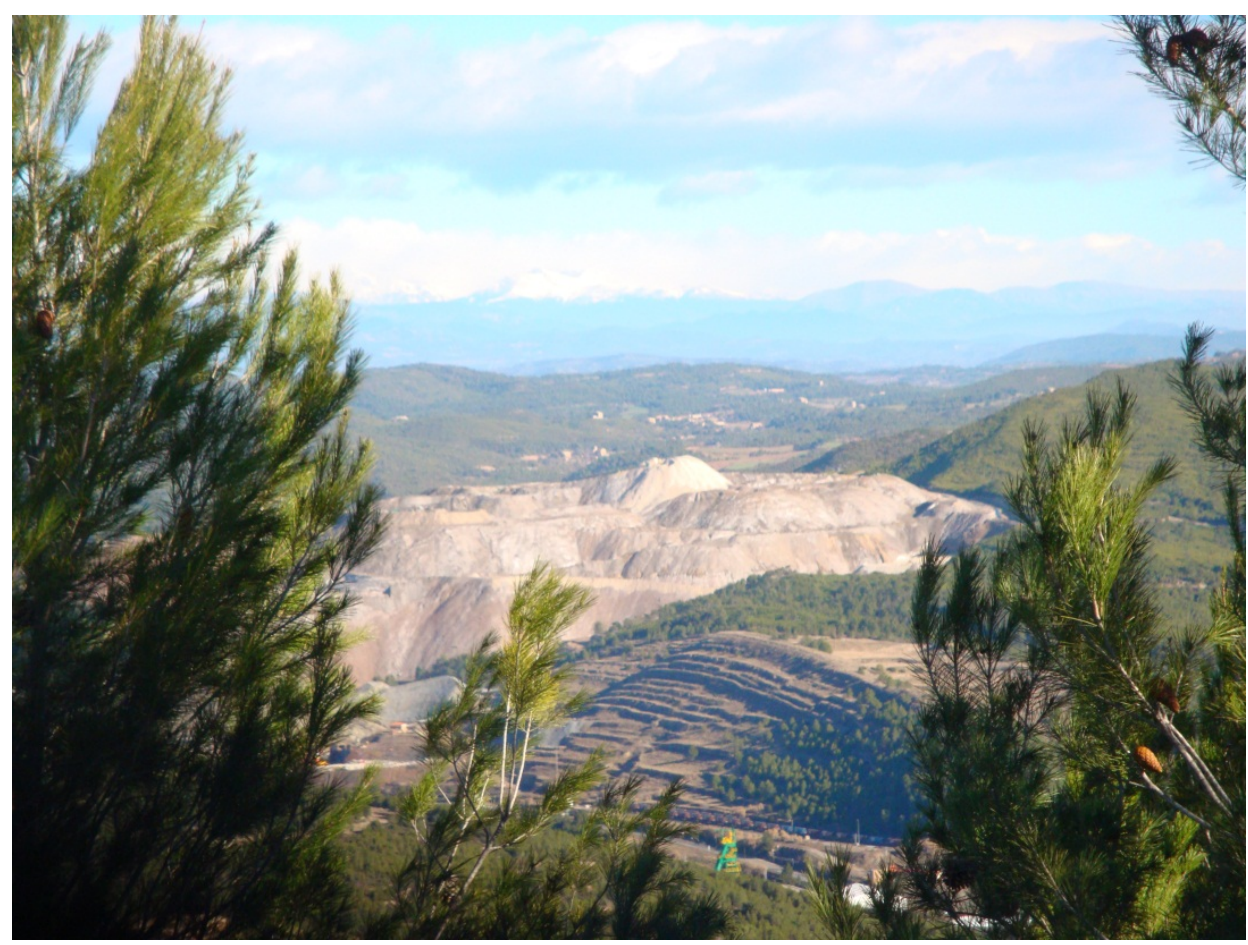

Fotografia 3. Escombreres de les explotacions de silvinita de Súria

Per d'altra banda, des d'aquest mateix indret, es poden veure les estructures de la denominada Anomalia de Castellnou. Aquesta es troba al SE de les escombreres, entre Castellnou de Bages i la carretera que uneix Súria amb Avinyó.

\subsection{Parada 4. Immediacions del trencall de la Vila, Moner i Bacardit, carretera BV - 3003, (Castelltallat, terme municipal de Sant Mateu de Bages, comarca del Bages). (Full 362).}

Desprès de realitzar l'aturada anterior, cal continuar el recorregut per la carretera local BV 3003, anant sempre cap a Ponent, cap a Castelltallat. Poc després de sobrepassar el trencall (per l'esquerra) que se'n va cap la Vila, Moner i Bacardit, farem una nova aturada, a uns $5 \mathrm{Km}$ de l'anterior.

En aquest recorregut, hem anat trobant els materials rogencs de la Formació Artés, tot i que sovint, per sota, haurem trobats els materials de la Formació Súria. Les dues formacions tenen 
alternances de gresos i de calcolutites, de totalitats roges a la Fm Artés, i de tonalitats grisenques a la Fm Súria. Aquests darrers són els que es troben a l'Indret de l'aturada.

Per d'altra banda, a mida que ens hem anat trobant a l'indret de l'aturada, els materials eocènics es van verticalitzant més, presentant inicialment un cabussament inclinat cap al Sud (fotografia 4). Més endavant, en arribar a l'indret de l'aturada, aquest cabussament es gairebé vertical (fotografia 5).

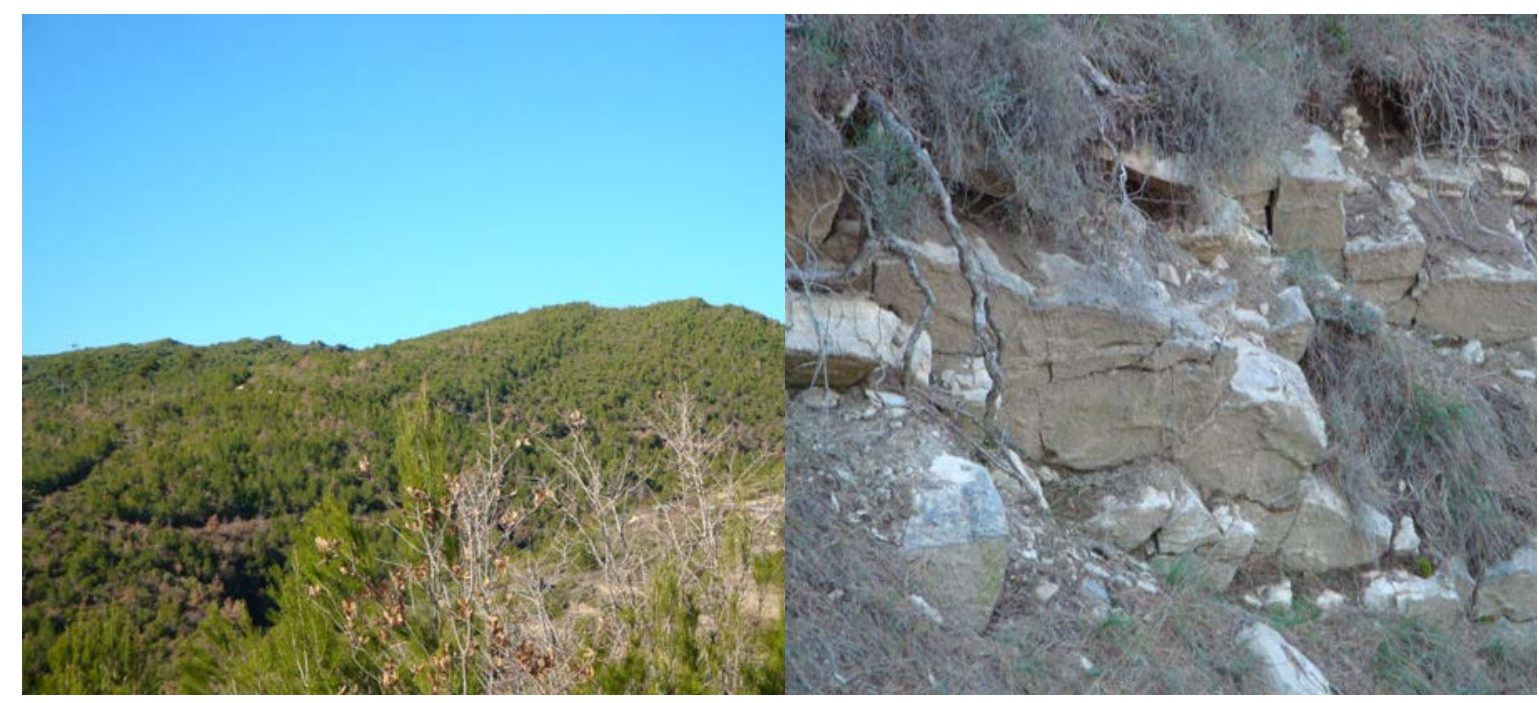

Fotografia 4 . Cabussament cap al Sud, visible pels relleus en

Fotografia 5. Cabussament clar cap al Sud costa

En aquest trajecte, hem anat ascendint pel flanc meridional, de I'Anticlinal de Súria, clarament asimètric. Així, en arribar a l'indret de l'aturada, hem arribat quasi al mateix pla axial del plec. Aquest es troba lleugerament al Nord, de l'indret on ara ens trobem situats.

Després, en continuar circulant per la carretera BV - 3003, a poca distància de l'indret anterior, a menys de 50 metres, mirant cap el barranc situat a la dreta de la carretera, observarem la existència d'un clar cabussament cap el Nord (fotografia 6). Això vol dir que hem sobrepassat el pla axial de l'anticlinal acabat d'esmentar.

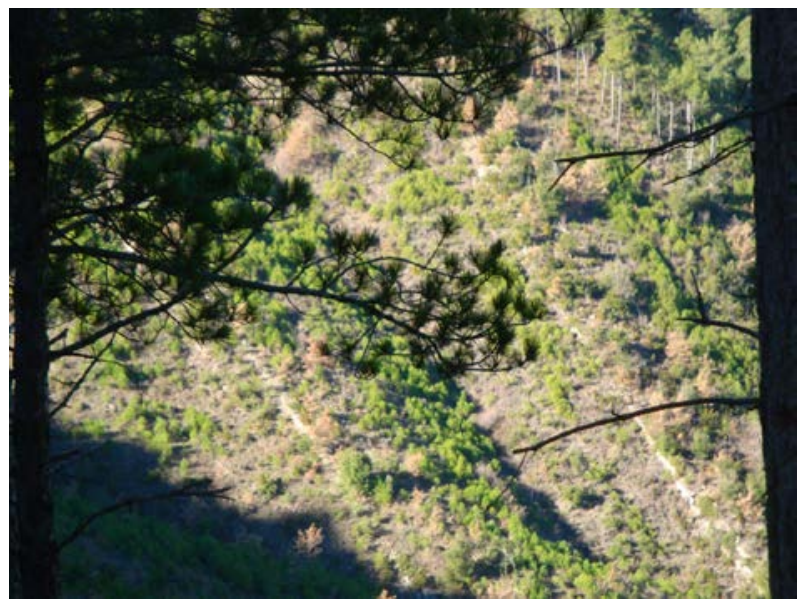

Fotografia 6. Cabussament clar cap al Nord, visible a l'altra banda del barranc

Xaragall.2014 n. 3 | Recorregut de recerca geològica i mineralògica per les comarques del Bages i del Solsonès: des de Callús i Sant Mateu de Bages cap a Castelltallat, Prades de la 


\subsection{Parada 5. Icnites de Can Prat Barrina, (Castelltallat, terme municipal de Sant Mateu de Bages, comarca del Bages). (Full 362).}

Desprès de realitzar l'aturada anterior, cal continuar el recorregut per la carretera local BV 3003, anant sempre cap a Ponent, cap a Castelltallat. Poc després de sobrepassar el trencall de la població, trobarem el brancal que es dirigeix cap a Salo y cap a la Molsosa. Així, començarem a baixar cap a les immediacions de Can Prat Barrina. Poc abans d'arribar-hi, trobarem l'indret on hi ha l'aflorament d'icnites, a la vora de la carretera, a ma esquerra baixant. En aquest lloc farem una nova aturada, a un $6 \mathrm{Km}$ de la realitzada anteriorment.

En aquest recorregut, hem sobrepassat el pla axial de I'Anticlinal de Súria i hem començat a baixar pel seu flanc septentrional. Així, haurem trobat que els estrats van cabussant cap el Nord.

Aquest és el cas dels afloraments de gresos carbonatats que hi ha a l'indret de la present aurada. Aquí apareix un interessant aflorament d'icnites de vertebrats. Aquest aflorament es troba molt ben senyalitzat i constitueix un element molt important del Patrimoni Geològic del Bages i en concret del Patrimoni Paleontològic d'aquesta comarca. (fotografies 7 i 8).

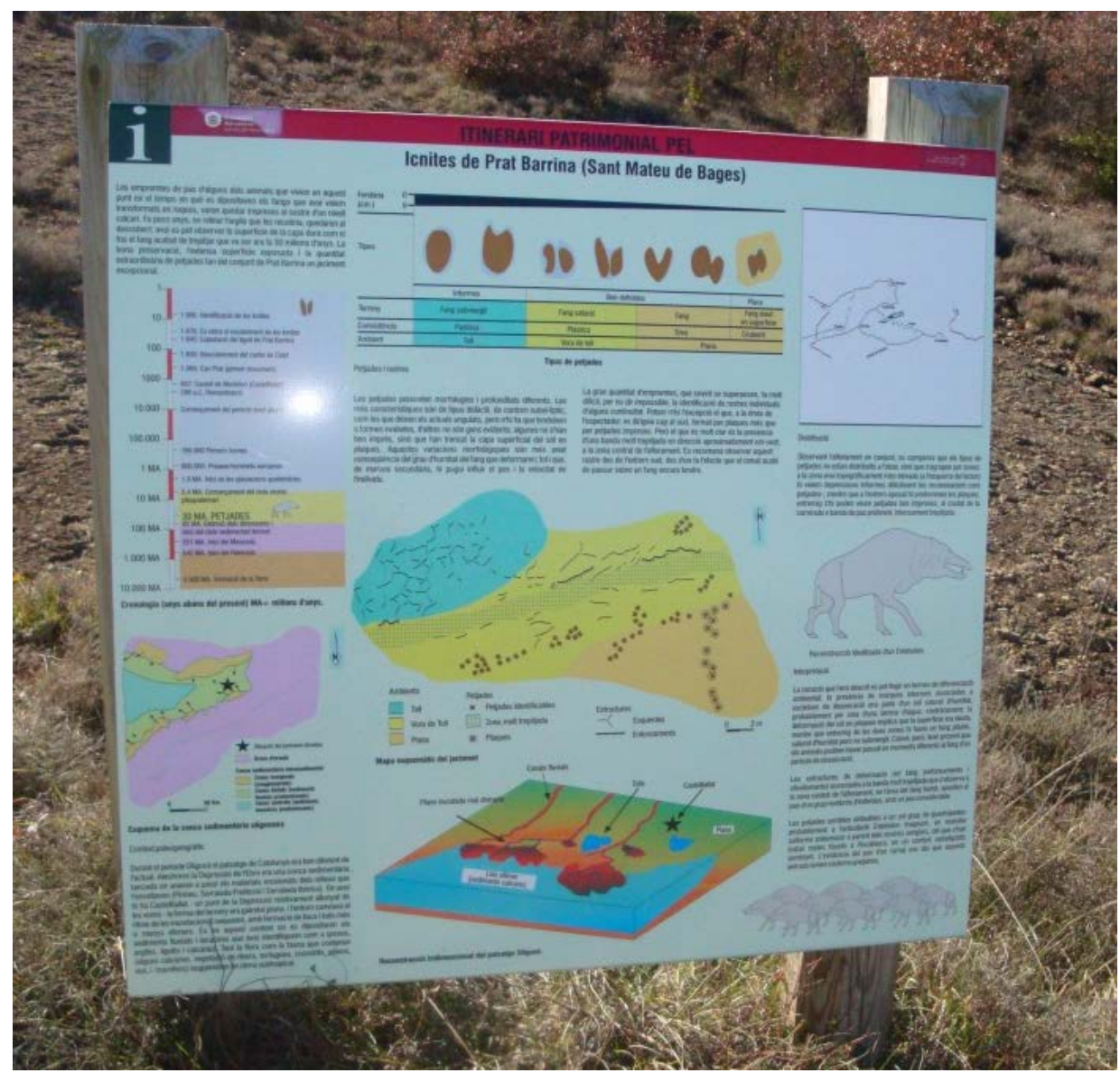

Fotografia 7. Plafó indicatiu de l'aflorament de les icnites

Xaragall.2014 n. 3 | Recorregut de recerca geològica i mineralògica per les comarques del Bages i del Solsonès: des de Callús i Sant Mateu de Bages cap a Castelltallat, Prades de la 


\subsection{Parada 6. Mina de lignit de Can Prat Barrina, (Castelltallat, terme municipal de Sant Mateu de Bages, comarca del Bages). (Full 362).}

Desprès de realitzar l'aturada anterior, cal acabar d'arribar fins a la masia de Can Prat Barrina. Després, ens caldrà agafar la pista que es dirigeix cap a Can Mil Homes. A menys de 0’5 Km de la primera masia esmentada i a uns 2 de la parada anterior, realitzarem la present aturada.

En aquest recorregut, hem continuat trobant afloraments del flanc septentrional de I'Anticlinal de Súria, on estem ara situats. Així, haurem trobat nivells de gresos de calcolutites inicialment grisenques de la Formació Súria. I també de tonalitats sovint rogenques. Aquests materials que pertanyen a la Formació Artés, son els que es troben a l'indret de la present aturada.

Aquí hi ha va haver unes antigues explotació dels lignits inclosos entre els materials de la Formació Artés. D'aquesta explotació es conserva les escombreres (amb restes de lignits) i també algunes de les bocamines. Normalment, es troben enrunades a uns 2 - 4 metres de les seves entrades. (fotografia 9).

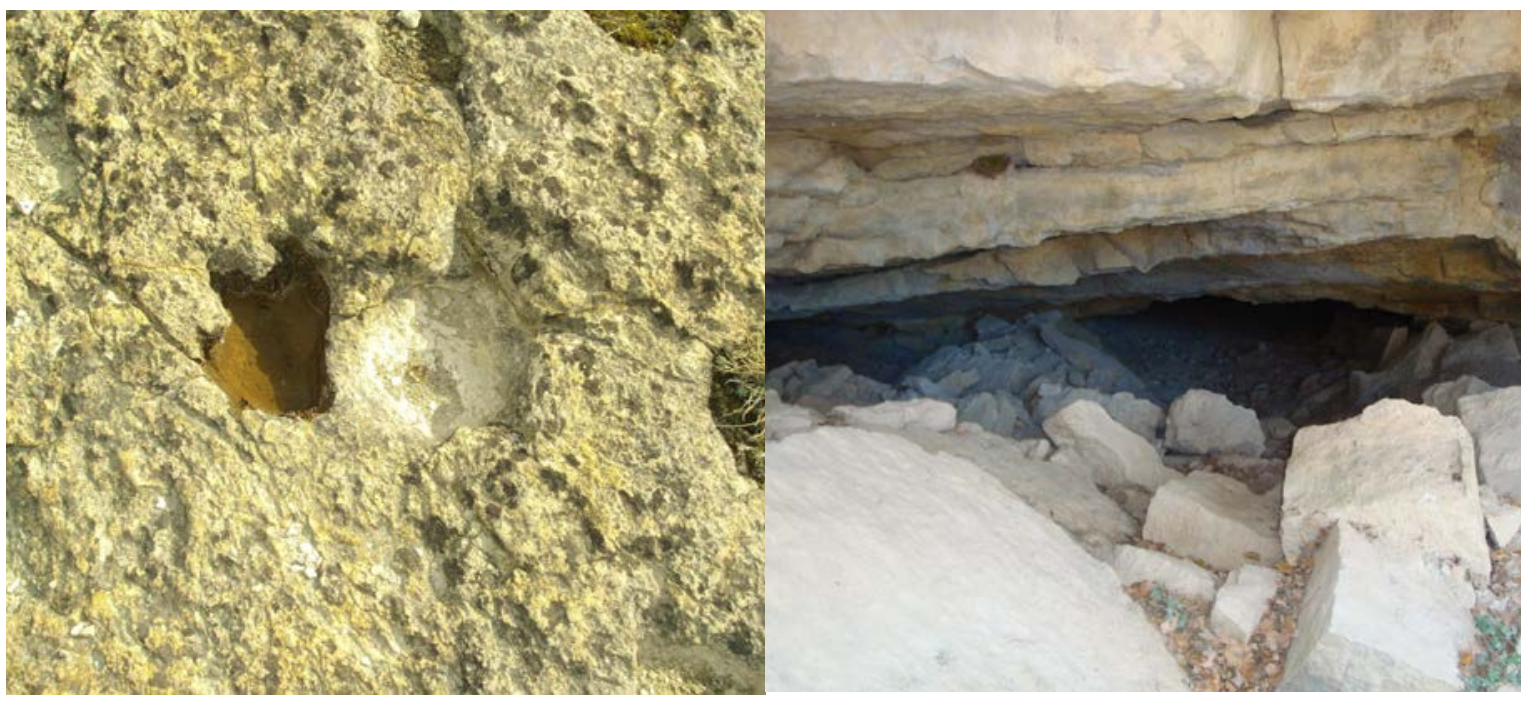

Fotografia 8. Un detall de l'aflorament. ( Josep Girabal)

Fotografia 9 Una de les bocamina esfondradades

\subsection{Parada 7. Carretera a Sant Pere dels Arcs, B - 300, (Sant Pere dels Arcs - Sant Pesselaç, terme municipal de Calaf, Comarca d'Anoia, Alta Segarra Calafina). (Full 362).}

Desprès de realitzar l'aturada anterior, cal retrocedir lleugerament, fins trobar la carretera local que es dirigeix cap a Prades i cap a la Molsosa. Ens caldrà agafar-la, passant per les proximitats de les dues poblacions acabades d'esmentar. En sobrepassar-les arribarem a les immediacions de Quadrells i poc després a la cruïlla amb la carretera B - 300, que uneix Pinós amb Calaf. En trobar aquesta carretera, ens caldrà anar cap al Sud, cap a Calaf. Poc abans 
d'arribar a la població de Sant Pere dels Arcs (o Sant Pesselaç), ens caldrà fer una nova aturada, després de recórrer uns $10 \mathrm{Km}$ des de la parada anterior.

En aquest recorregut, haurem estat circulant pel flanc septentrional de l'Anticlinal de Súria, que ja hem trobat a la parada anterior. Així, haurem trobat els materials de la Formació Artés, amb gresos i calcolutites rogenques. També haurem trobat els materials de la Formació Súria, amb gresos i calcolutites grisenques; i fins i tot nivells guixosos d'aquesta darrera formació, prop de Quadrells.

En els darrers trams d'aquest recorregut, ens hem estat apropant al pla axial de I'Anticlinal de Súria, especialment entre els Quadrells i Sant Pere dels Arcs. Així, prop d'aquesta darrera població, els materials cabussen cap al Sud. És a dir: haurem passat del flanc septentrional al flanc meridional de l'Anticlinal de Súria, després de sobrepassar el pla axial del mateix. (fotografia 10).

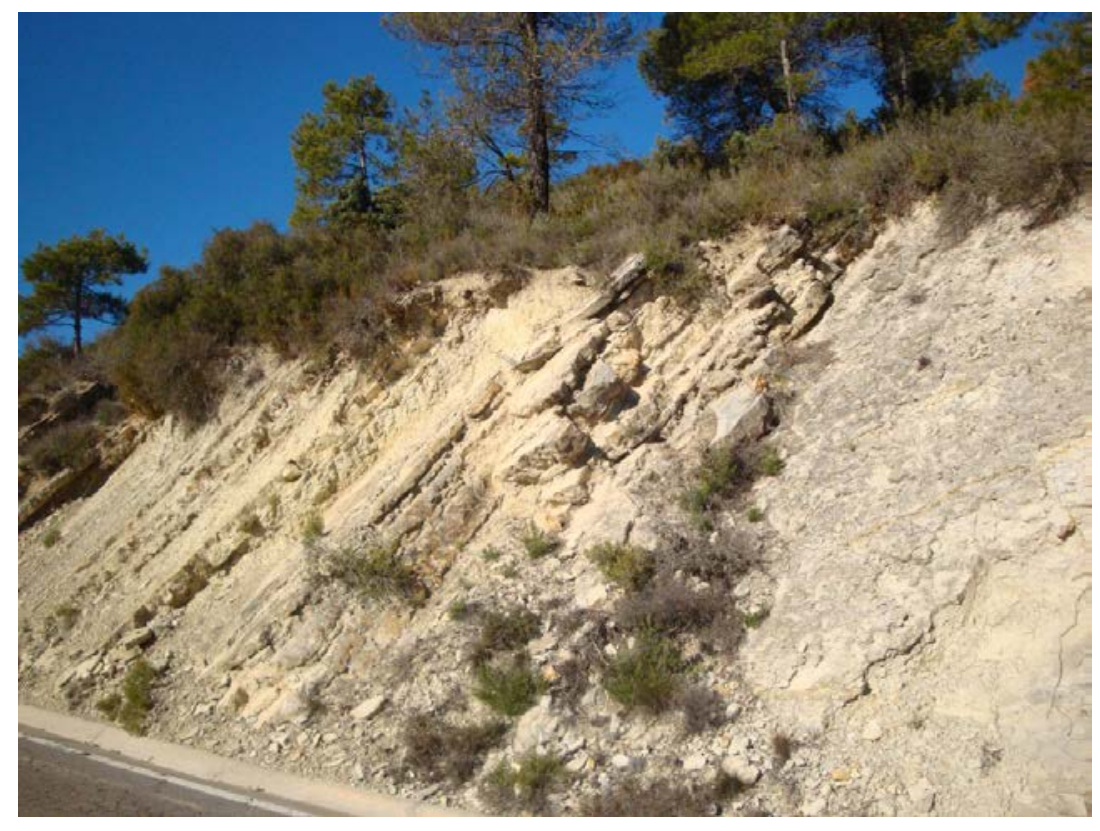

Fotografia 10 . Flanc meridional de l'Anticlinal de Súria, prop de Sant Pere dels Arcs

\subsection{Parada 8. Base del turó del poble de Pinós, carretera al santuari, B - 300, (terme municipal de Pinós, Comarca del Solsonès). (Full 330).}

Desprès de realitzar l'aturada anterior, cal retrocedir per la carretera $B-300$, arribant fins a la cruïlla amb la carretera procedent de la Molsosa, per on hem vingut. Després, ens caldrà seguir cap al Nord, per aquesta mateixa carretera B - 300. Poc després, deixarem a l'esquerra el trencall que es dirigeix cap a Castellfollit de Riubregós. Més endavant arribarem a les immediacions del poble de Pinós, deixant a la dreta el trencall que puja cap el poble. Poc després, en arribar a la base del turó sobre el que s'assenta la població de Pinós, farem una nova aturada, a uns $10 \mathrm{Km}$ de la parada anterior.

En aquest recorregut, hem anat trobat afloraments dels materials esmentats a les aturades anteriors. En bona part, aquests materials pertanyen a la Formació Súria i es troben constituïts per nivells de calcolutites i gresos de tonalitats grisenques. També hem trobat, especialment als

Xaragall.2014 n. 3 | Recorregut de recerca geològica i mineralògica per les comarques del Bages i del Solsonès: des de Callús i Sant Mateu de Bages cap a Castelltallat, Prades de la 
darrers trams, nivells de calcolutites i gresos rogencs, els quals pertanyen a la Formació Artés, com ara l'indret de l'aturada.

Per d'altra banda, en bona part del recorregut, haurem trobat aquests materials amb un cabussament generalitzat cap el Nord, tot formant part del flanc septentrional de I'Anticlinal de Súria. Prop de l'indret de l'aturada, aquests materials presenten algunes inflexions, com a I'indret on ara som. (fotografia 11).

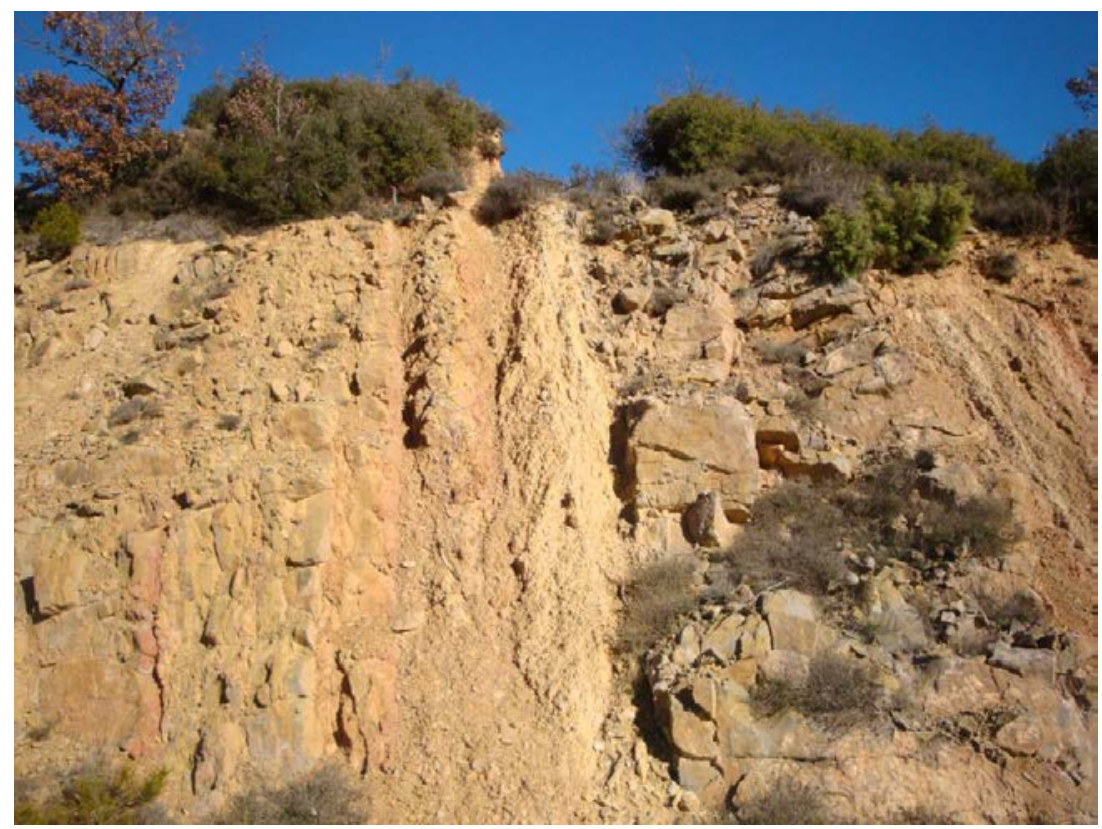

fotografia 11 Materials de la Formació Artés, afectats per I’Anticlinal de Cardona, a la base del turó de Pinós

Efectivament, en aquest indret, ens trobem davant d'uns materials afectats per I'Anticlinal de Cardona. És a dir, hem passat quasi imperceptiblement del flanc septentrional de I'Anticlinal de Súria al flanc meridional de I'Anticlinal de Cardona. Tots dos de direcció pràcticament d’Est a Oest.

Així, molt probablement, ara ens trobem molt propers a la zona axial del darrer anticlinal esmentat.

\subsection{Parada 9. Immediacions del Santuari de Pinós, (terme municipal de Pinós, Comarca del Solsonès). (Full 330).}

Desprès de realitzar l'aturada anterior, cal continuar per la carretera B -300 , amb la intenció d'arribar fins al Santuari de Pinós. En arribar-hi, podem agafar un camí que es dirigeix cap a llevant, cap a les antenes de televisió. Prop d'aquest indret, podem fer una nova aturada, a uns $6 \mathrm{Km}$ de I'anterior. 
En aquest recorregut, haurem trobat afloraments dels materials rogencs de la Formació Artés. Aquests materials es troben força inclinats cap al Nord, tot formant part del flanc septentrional de I'Anticlinal de Cardona, on ens trobem ara situats. Des de l'indret de I'aturada es ben palès aquest cabussament generalitzat. (fotografia 12).

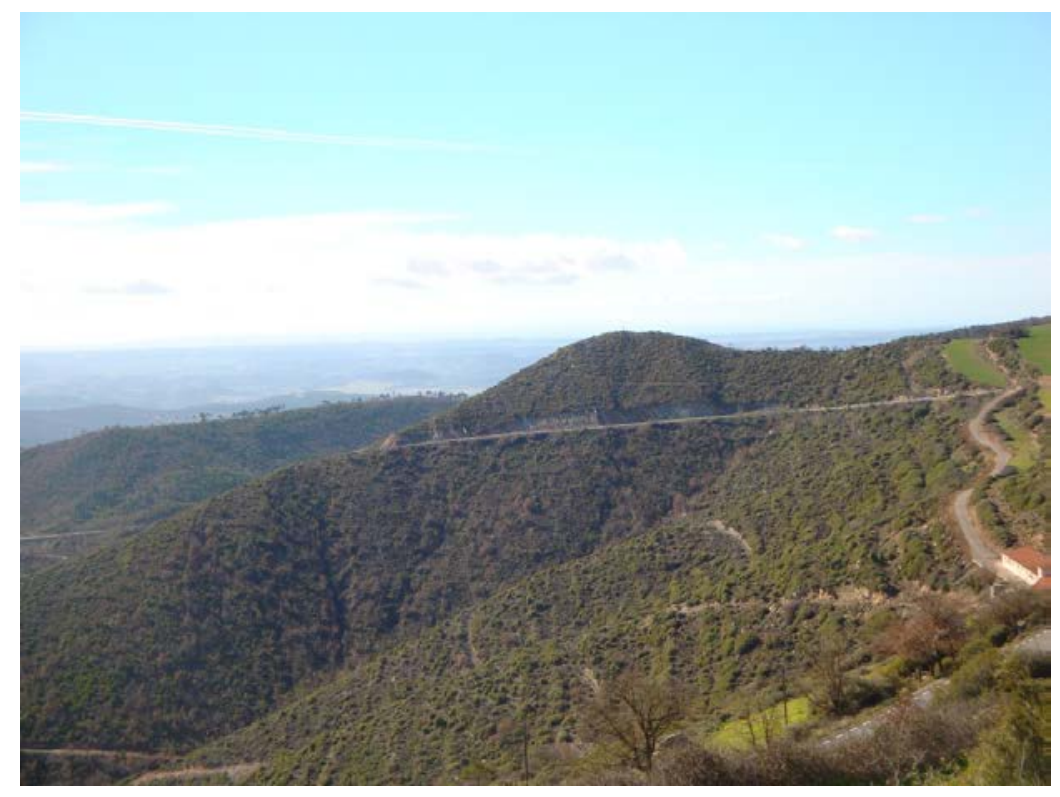

Fotografia 12. Cabussament generalitzat cap el Nord (visible per les feixes de vegetació), pel Santuari de Pinós

\subsection{Parada 10. Trencall de Matamargó, (Matamargó, terme municipal de Pinós, Comarca del Solsonès). (Full 330).}

Desprès de realitzar l’aturada anterior, cal continuar per la carretera B -300, amb la intenció d'arribar fins al poble de Su, deixant a l'esquerra el trencall d'Ardèvol. Després, en arribar a Su, ens caldrà seguir per la carretera BV - 3001, la qual condueix cap a Cardona, entrant lleugerament a la comarca del Bages. Poc després, trobarem per la dreta el trencall de Matamargó i Vallmanya, que ens caldrà agafar. Així tornarem a entrar a la comarca del Solsonès. Més endavant, en arribar al trencall del poblet de Matamargó farem una nova aturada, a uns $15 \mathrm{Km}$ de I'anterior.

En aquest recorregut, hem continuat trobant els materials esmentats a l'aturada anterior. I com en aquell cas, presenten un cabussament generalitzat cap al Nord. Aquests materials formen part del franc septentrional de I'Anticlinal de Cardona, per on hem estat circulant en aquest trajecte.

Tot i així, des de l'indret de l'aturada, mirant cap a llevant, es pot entreveure clarament I'esmentat anticlinal. Aquest queda palès veient els relleus en costa dels materials cenozoics de la Formació Artés. (fotografia 13). 


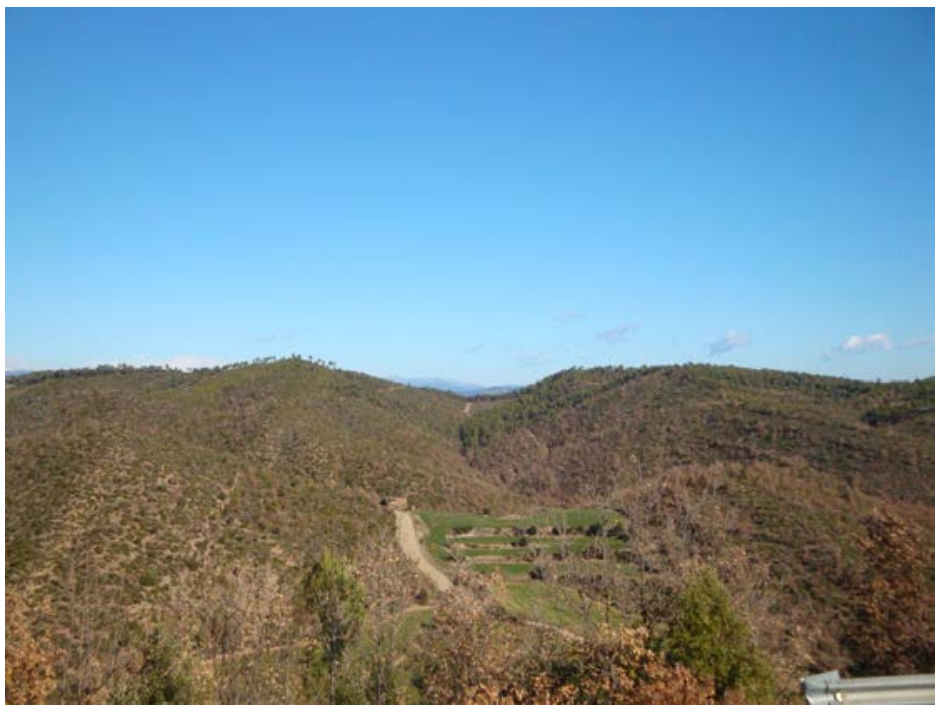

Fotografia 13 . L’Anticlinal de Cardona, des del trencall de Matamargó.

Aquests relleus en costa es fan palesos pe arreu i son visibles observant les feixes de la vegetació. A les parts altres es troben els nivells de gresos, mentre que a les cuestes es situen les calolutites. (Fotografia 14).

\subsection{Parada 11 - Condicional. Trencall de Matamargó, (Matamargó, terme municipal de Pinós, Comarca del Solsonès). (Full 330).}

Desprès de realitzar \'aturada anterior, cal continuar per la carretera cap el Sud, amb la intenció d'arribar al Pont de Vallmanya. En arribar-hi, si s'escau, farem la darrera aturada dl recorregut, a uns 4 Km de 'anterior. La farem a I cruillla amb la carretera B -3002 (Salo - Vallmanya).

En aquest recorregut, hem trobat els materials rogencs de la Formació Artés, els quals constitueixen aquí el flanc meridional de l'Anticlinal de Cardona, presentant un clar cabussament cap el Sud.

Tot i així, a l'indret de aturada, ja veurem els materials grisencs de la Formació Súria, els quals formen part del flanc septentrional de l'Anticlinal de Súria, que s'estén al Sud d'on ara som. Aquests materials tenen un clar cabussament cap al Nord. 


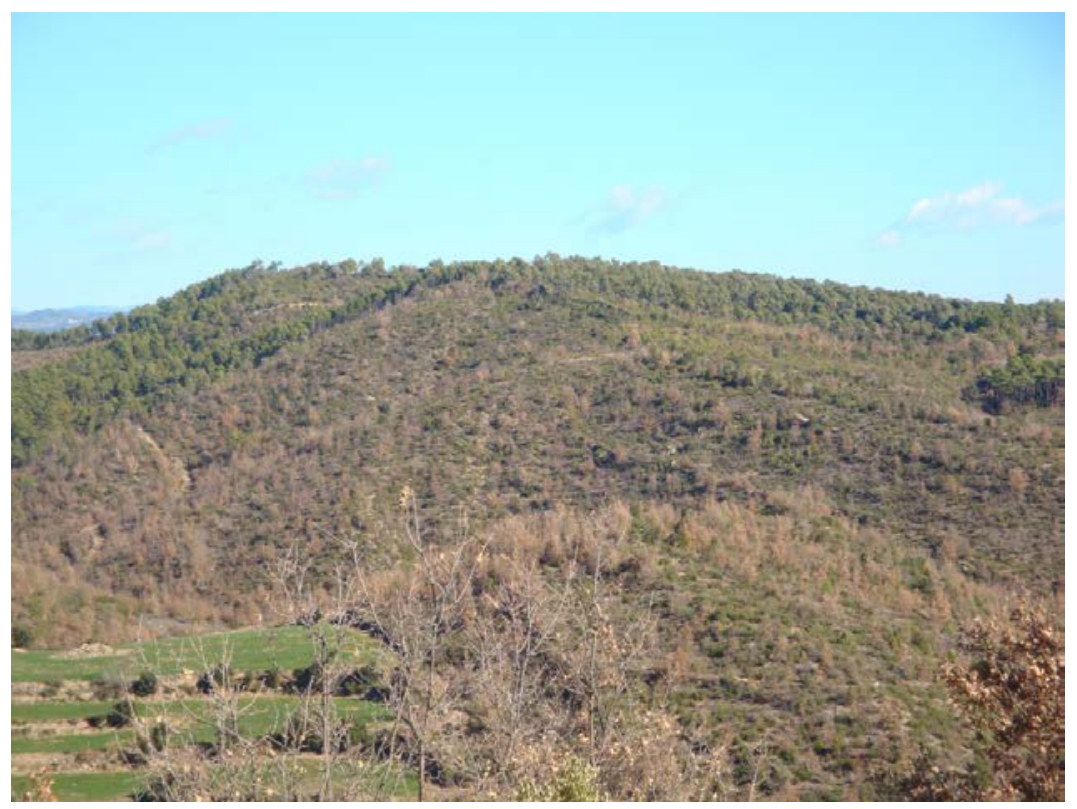

Fotografia 14. Un aspecte dels relleus en costa, al Sud de l'Anticlinal de Cardona

En aquest indret finalitza el recorregut de l'itinerari.

\section{Referències Bibliogràfiques}

GUIMERÀ, J. et altri (1992).- Geologia (II), Història Natural dels Països Catalans, Vol. 2, 547 pag. Enciclopèdia catalana, S.A., Barcelona

IGME (1975).- Mapa Geológico de España a Escala 1:50.000 (2a Sèrie). Full i Memòria no 330 (Cardona). Inst. Tecnológico y GeoMinero de España. Minist. Indus. Ener. Madrid

IGME (1982).- Mapa Geológico de España a Escala 1:50.000 (2ª Sèrie). Full i Memòria $n^{0} 362$ (Calaf). Inst. Tecnológico y GeoMinero de España. Minist. Indus. Ener. Madrid

MATA-PERELLÓ, J.M. (1984).- Depressió Central o Depressió de I’Ebre, Revista Dovella, $n^{\circ}$ 36, pp 85-89. Manresa

MATA-PERELLÓ, J.M. (1991).- Els Minerals de Catalunya. Arxius de la Secció de Ciències, t. XCIII. 442 pàgines, Institut d’Estudis Catalans. Barcelona

MATA-PERELLÓ, J.M. (1994).- Inventari Mineralògic de la comarca del Solsonès. Xaragall, 14, 30 pàgines. Manresa

RIBA ARDERIU, O. (1967).- Resultados de un estudio sobre el terciário continental de la parte Este de la Depresión Central Catalana. Acta Geológica Hispánica, t.. 2, Vol.1, pp. 3-8. Barcelona

RIBA ARDERIU, O. Et altri. (1976).- Geografía física dels Països Catalans. Edit Ketres, 205 pàgines. Barcelona 